\title{
EFEKTIFITAS RASIO NUTRIEN BAKTERI Bacillus cereus STRAIN IMB-11 DALAM MENDEGRADASI PENCEMARAN BIOSOLAR SEBAGAI RANCANGAN POSTER BIOLOGI SMA
}

\author{
Desrianty Syafitri $^{1^{*}}$, Irda Sayuti $^{2)}$, Imam Mahadi $^{3)}$ \\ ${ }^{1 *}$ Email: desriantysyafitri07@gmail.com \\ ${ }^{2)}$ Email: irda.sayuti@lecturer.unri.ac.id \\ ${ }^{3)}$ Email: imam.mahadi@lecturer.unri.ac.id \\ 1) 2) ${ }^{3)}$ Program Studi Pendidikan Biologi, FKIP Universitas Riau
}

\begin{abstract}
This study aims to controlling environmental pollution by biodiesel using Bacillus cereus Strain IMB-11 bacteria by optimizing the nutrient ratio of bacteria. This research was conducted at the microbiology laboratorium medicine fakulty of Riau University in December 2020-February 2021. The media used were SMSS media with the addition of variations carbon, nitrogen and fosfor ratio (100:10:1, 100:10:0.5, 100:5:1 and 100:5:0,5) which added 10\% bacteria Bacillus cereus strain IMB-11. The test parameter was the visual observation and total bacterial colony of Bacillus cereus bacteria Strain IMB-11 which was seen using a spectrophotometer for 7 days measuring. Based on the research, it was found that C:N:P 100:10:1 was the best nutrient ratio concentration for the growth of Bacillus cereus bacteria Strain IMB-11 with total bacterial colony $2.42 \times 10^{9} \mathrm{CFU} / \mathrm{mL}$ on day 3, and changes in the color and turbidity of the media that occur faster than other nutrient ratio variations. The results can be used as a poster design on Bacteria material for class X high school. The conclusion of this study is that the nutrient ratio $C: N: P=10: 10: 1$ provides more optimal growth of the bacteria Bacillus cereus Strain IMB-11 compared to other nutrient ratios and the results of the study can be used as a poster media design for bacteria class X SMA 3.5 Identifying the structure, way of life, reproduction and role of bacteria in life and KD 4.5 Presenting data about the characteristics and roles of bacteria in life.
\end{abstract}

Keywords: Bacillus cereus strain IMB-11bacteria; biosolar waste; nutrient ratio; poster design

\section{ABSTRAK}

Tujuan dari penelitian adalah untuk mengendalikan pencemaran lingkungan oleh biosolar menggunakan bakteri Bacillus cereus strain IMB-11 dengan mengoptimalkan rasio nutrisi bakteri. Penelitian dilakukan pada Desember 2020-Januari 2021 di laboratorium Mikrobiologi, Fakultas Kedokteran Universitas Riau. Media yang digunakan adalah SMSS dengan menambahkan 4 variasi rasio nutrien berupa karbon, nitrogen dan Fosfor dengan rasio 100:10:1, 100:10:0.5, 100:5:1 dan 100:5:0,5 dengan menambahkan 10\% bakteri Bacillus cereus strain IMB-11. Parameter yang diamati adalah perubahan warna dan kekeruhan media kultur serta jumlah koloni bakteri dalam mendegradasi biosolar. Rasio nutrien $\mathrm{C}: \mathrm{N}: \mathrm{P}$ 100:10:1 memberikan pertumbuhan optimal bagi bakteri dalam mendegradasi biosolar, terlihat dari jumlah koloni yang lebih tinggi yaitu mencapai $2.42 \times 10^{9} \mathrm{CFU} / \mathrm{mL}$ pada hari ke 3 , serta perubahan warna dan kekeruhan media yang cenderung terjadi lebih cepat dibandingkan variasi rasio nutrien lainnya. Hasil penelitian dapat dijadikan sebagai media pembelajaran Poster pada materi bakteri kelas X SMA. Kesimpulan dari penelitian ini yaitu Rasio nutrien C:N:P=10:10:1 memberikan pertumbuhan lebih optimal terhadap bakteri Bacillus cereus Strain IMB-11 dibandingkan dengan rasio nutrien lainnya dan hasil penelitian dapat 
dijadikan sebagai rancangan media poster materi Bakteri kelas X SMA 3.5 Mengidentifikasi struktur, cara hidup, reproduksi dan peran bakteri dalam kehidupan dan KD 4.5 Menyajikan data tentang ciri-ciri dan peran bakteri dalam kehidupan.

Kata Kunci: Bakteri Bacillus cereus strain IMB-11; limbah biosolar; rasio nutrien; poster

\section{PENDAHULUAN}

Tingginya konsumsi dan aktivitas industri Biosolar memberikan dampak positif dalam kehidupan, namun jika konsumsi dan aktivitas industri biosolar tidak terkontrol maka akan berdampak negatif terhadap lingkungan baik secara biologi, kima maupun fisika. Pencemaran dapat terjadi akibat sisa bahan bakar mesin yang menggunakan biosolar sebagai bahan bakarnya terutama pada sektor industri kelapa sawit, pencemaran juga disebabkan kebocoran pipa penyalur atau rembesan biosolar melalui tanah dan rembesan bahan bakar biosolar dari kendaraan terutama kendaraan laut khusunya di pelabuhan. Selain hal tersebut, pencemaran oleh biosolar juga dapat mencemari udara akibat hasil pembakaran. Pencemaran oleh Biosolar yang mengandung senyawa hidrokarbon polisiklik, hidrokarbon alifatik (n-alkana), siklo-alkana, isoalkana serta minyak kelapa sawit yang merupakan molekul metil ester dapat mengakibatkan kerusakan ekosistem yang disebabkan penumpukan senyawa tersebut di dalam tubuh organisme di sekitar lokasi tercemar (Kristinanda, 2018).

Oleh karena itu dibutuhkan usaha efektif untuk mengatasi pencemaran lingkungan oleh biosolar, salah satunya yaitu menggunakan teknik Bioremediasi dengan pemanfaatan mikroba yang akan mengurai pencemar lingkungan (Andareas, 2019). Salah satu bakteri yang dapat mendegradasi bahan bakar Biosolar adalah Bacillus cereus strain IMB-11 (Isolat Minyak Bumi-11 atau Hidrocarbonoclastic bacterial isolates-11). Bakteri Bacillus cereus strain IMB-11 adalah Bakteri Hidrokarbonoklastik hasil penelitian Irda Sayuti, et al., (2018) yang ditemukan di Waste Tanks, Petapahan, Riau, Indonesia, menggunakan 16s rRNA dan teruji dapat mendegradasi senyawa fenolik dalam minyak bumi hingga $83 \%$.

Untuk mengoptimalkan kemampuan bakteri Bacillus cereus strain IMB-11 dalam mendegradasi pencemaran lingkungan oleh Biosolar, maka pertumbuhan bakteri tersebut juga harus optimal. Mengoptimalkan pertumbuhan bakteri dapat dilakukan dengan cara mengoptimalkan faktor tumbuh dari bakteri tersebut, salah satunya yaitu nutrisi.

Unsur makronutrien yang dibutuhkan bakteri adalah karbon $(\mathrm{C})$, nitrogen $(\mathrm{N})$, dan Fosfor (P). unsur- unsur tersebut harus tercukupi dalam rasio yang seimbang sehingga bakteri dapat tumbuh optimal (Wulan, 2016). Metabolisme bakteri sangat dipengaruhi oleh keseuaian rasio CNP, maka perlu diketahui rasio optimal nutrisi untuk pertumbuhan bakteri tersebut agar bakteri 
mampu mendegradasi polutan secara optimal.

Pengetahuan tentang bakteri termasuk dalam pelajaran Biologi SMA kelas X. Berdasarkan wawancara di beberapa SMA di Kabupaten Kampar, didapati bahwa dalam proses pembelajaran pada materi Bakteri hanya menggunakan LKPD MGMP dan Buku Teks Pelajaran saja dan belum adanya pengembangan media poster, khususnya poster bakteri dan peranannya bagi lingkungan. Selain itu materi bakteri termasuk kedalam cabang mikrobiologi yang pada umumnya sulit dipahami siswa secara visual, misalnya siswa kesulitan dalam menjelaskan dan membedakan siklus atau fase hidup bakteri serta kesulitan dalam menggambar struktur bakteri yang terkadang tidak dijumpai di buku sumber belajar. Hal ini dibuktikan oleh rendahnya nilai tes atau ulangan harian siswa pada materi tersebut. Oleh karena itu guru perlu mengembangkan media pembelajaran yang menonjolkan pesan berupa gambar visual, seperti media pembelajaran Poster.

Ningsih (2018) memaparkan bahwa poster adalah suatu pesan tertulis baik itu berupa gambar atau pun tulisan yang ditunjukkan untuk menarik perhatian banyak orang sehingga pesan yang disampaikan dapat diterima orang lain dengan mudah. Media poster dinilai mampu mengikuti kemajuan Ilmu Pengetahuan dan Teknologi (IPTEK) khususnya dibidang pendidikan. Media poster dapat berupa Hard file maupun Soft file, dalam bentuk Hard file poster tidak memerlukan media penunjang lainnya, cukup di gantungkan atau tempelkan pada dinding sedangkan dalam bentuk Soft file tidak memerlukan ruang penyimpanan yang besar pada perangkat elektronik seperti Handphone maupun $P c$, sehingga guru dan siswa bisa mengakses media poster kapanpun dan dimanapun dengan mudah. Selain itu seorang guru profesional harus mampu menciptakan kegiatan pembelajaran yang menarik dan tidak membosankan agar tercipta kegiatan pembelajaran yang aktif dan mampu meningkatkan motivasi dan hasil belajar siswa. Salah satu langkah yang dapat dilakukan guru adalah dengan menggunakan perangkat pembelajaran yang bervariasi, salah satunya yaitu poster. Tujuan dari penelitian adalah untuk mengendalikan pencemaran lingkungan oleh biosolar menggunakan bakteri Bacillus cereus strain IMB-11 dengan mengoptimalkan rasio nutrisi bakteri serta mengembangkan poster pembelajaran yang berbasis riset penelitian.

\section{METODE PENELITIAN}

Penelitian dilakukan pada Desember 2020-Januari 2021 di laboratorium Mikrobiologi, Fakultas Kedokteran Universitas Riau. Media yang digunakan adalah SMSS (Stone mineral salt solution) dengan menambahkan 4 variasi rasio nutrien berupa karbon, nitrogen dan Fosfor dengan rasio 100:10:1, 100:10:0.5, 100:5:1 dan 100:5:0,5 kemudian ditambahkan 10\% bakteri Bacillus cereus strain IMB-11. Bahan bakar Biosolar B20 sebagai sumber Carbon (C), amonium nitrat 
sebagai sumber Nitrogen $(\mathrm{N})$ dan pupuk Superposfat sebagai sumber Fosfor $(\mathrm{P})$. Biosolar B20 mengandung unsur karbon dengan rentang C12 - C18. Parameter yang diamati adalah perubahan warna dan kekeruhan media kultur yang diamati secara visual selama 7 hari kultivasi, serta jumlah koloni bakteri dalam mendegradasi biosolar yang diperoleh dengan menghitung jumlah koloni bakteri tiap 24 jam sekali selama 7 hari dengan alat colony counter menggunakan metode TPC (Total Plate Count). Data yang diperoleh dianalisis secara deskriptif selanjutnya di tampilkan dalam bentuk tabel dan grafik untuk di ambil suatu kesimpulan. Sedangkan tahap perancangan poster dilakukan pada Januari-Februari 2021di Kampus Binawidya, program studi Pendidikan Biologi, Fakultas Keguruan dan Ilmu Pendidikan Universitas Riau. Tahap ini terdiri atas tahap analisis dan perancangan.

\section{HASIL DAN PEMBAHASAN}

\section{a. Pengamatan Visual Pertumbuhan Bakteri Bacillus cereus strain IMB-11 dalam mendegradasi Biosolar}

Pengamatan secara visual dilakukan dengan cara mengamati perubahan warna dan kekeruhan media kultur bakteri Bacillus cereus strain IMB-11 pada media SMSS yang sudah di tambahkan biosolar sebanyak 10\%. Hasil Kultivasi isolat bakteri yang telah diberi perlakuan ditampilkan pada Gambar 1:

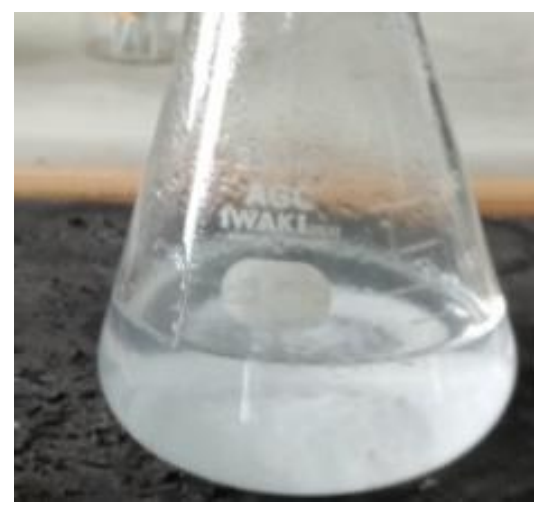

(a)

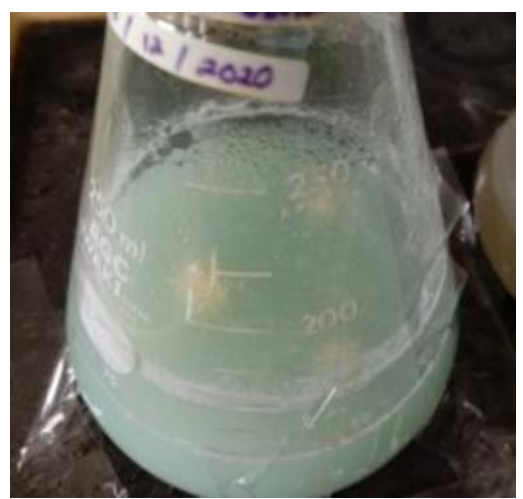

(b)

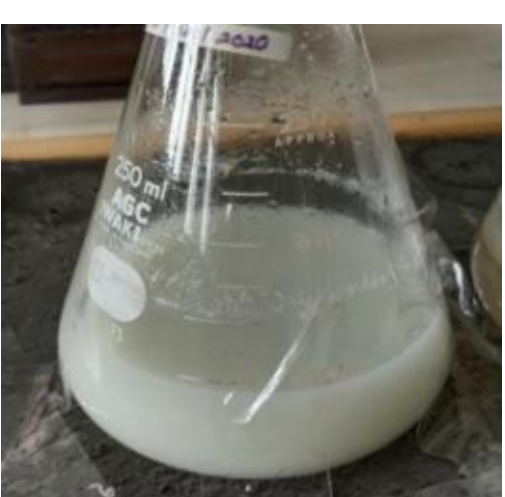

(c)

Gambar 1. Hasil Kultivasi Bakteri Bacillus cereus strain IMB-11, (a) Hari pertama; (b) Hari ke empat; (c) Hari ke-tujuh 


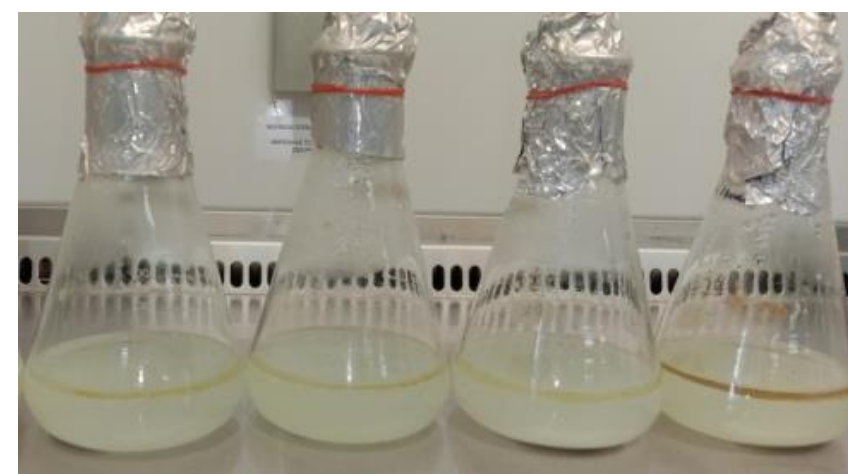

(a)

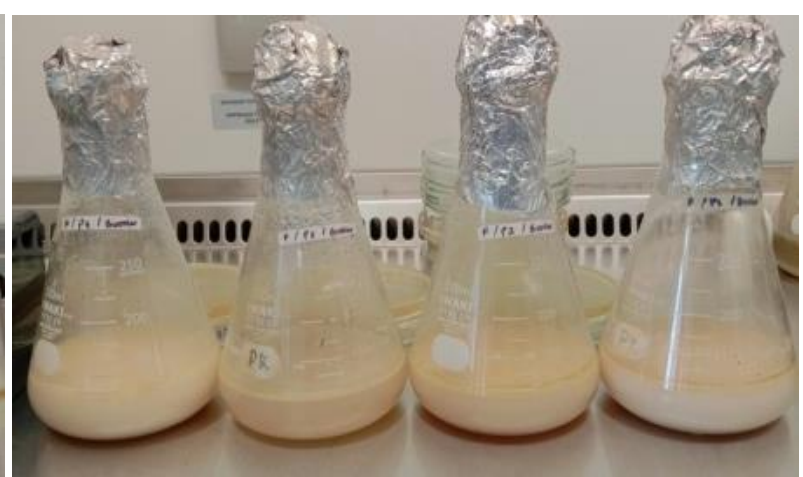

(b)

Gambar 2. Perbandingan hasil kultivasi bakteri Bacillus cereus strain IMB-11 sebelum dan sesudah diberi perlakuan, (a) Hari ke-1; (b) Hari ke-7

Berdasarkan gambar 1 dapat dilihat bahwa media SMSS mengalami perubahan warna dari hari ke hari. Pada hari pertama setelah isolat bakteri di kultivasi, media SMSS berwarna bening. Setiap hari media SMSS menunjukkan perubahan warna yang semakin keruh, hingga pada hari ke tujuh media SMSS berubah warna menjadi putih susu. Berdasarkan hasil pengamatan secara visual, perubahan warna dan kekeruhan pada media SMSS serta perubahan kondisi Biosolar cenderung terjadi lebih cepat pada perlakuan 1 yaitu dengan rasio nutrien $\mathrm{C}: \mathrm{N}: \mathrm{P}=100: 10: 1$. Hasil pengamatan visual pada media SMSS dapat dilihat pada tabel 1

Perubahan warna pada media SMSS dari mulanya bening menjadi semakin keruh juga disebabkan oleh bakteri Bacillus cereus Strain IMB-11 yang mulai memasuki fase eksponensial dimana bakteri Bacillus cereus Strain IMB-11 mulai berkembangbiak sehingga jumlah sel bakteri Bacillus cereus Strain IMB-11 dalam media SMSS tersebut semakin banyak. Selain hal tersebut, perubahan kepekatan warna media SMSS juga disebabkan karena terbentuknya metabolit-metabolit sekunder sisa metabolisme bakteri Bacillus cereus Strain IMB-11. Hasil pengamatan visual bakteri Bacillus cereus strain IMB-11 yang telah diberi perlakuan ditampilkan pada Tabel 1: 
Tabel 1. Hasil pengamatan visual kultivasi bakteri Bacillus cereus strain IMB-11 yang telah diberi perlakuan

\begin{tabular}{|c|c|c|}
\hline \multirow{2}{*}{$\begin{array}{l}\text { Waktu } \\
\text { inkubasi } \\
\text { (Jam) }\end{array}$} & \multicolumn{2}{|r|}{ Pengamatan } \\
\hline & Warna Media Kultur & Kondisi Biosolar \\
\hline $24 \mathrm{Jam}$ & bening & $\begin{array}{l}\text { Biosolar menyebar membentuk lapisan yang menutupi permukaan } \\
\text { media kultur (sama pada setiap rasio nutrien) }\end{array}$ \\
\hline $48 \mathrm{Jam}$ & Bening kuning kehijauan & $\begin{array}{l}\text { Biosolar menyebar membentuk lapisan cekung yang menutupi } \\
\text { permukaan media kultur (sama pada setiap rasio nutrien). }\end{array}$ \\
\hline $72 \mathrm{Jam}$ & Keruh keabu-abuan & $\begin{array}{l}\text { Lapisan Biosolar pecah membentuk butiran-butiran menutupi lapisan } \\
\text { permukaan media kultur (pecahan butiran-butiran Biosolar terlihat } \\
\text { dalam jumlah yang lebih banyak pada rasio nutrien } 1 \& 2 \\
\text { dibandingkan rasio nutrien } 3 \& 4 \text { ). }\end{array}$ \\
\hline $96 \mathrm{Jam}$ & Keruh keabu-abuan & $\begin{array}{l}\text { Butiran-butiran Biosolar berubah menjadi butiran yang lebih kecil } \\
\text { (Butiran-butiran Biosolar pada rasio nutrien } 1 \& 2 \text { lebih halus dan } \\
\text { terlihat dalam jumlah yang lebih banyak dibandingkan rasio nutrien } \\
3 \& 4 \text { ). }\end{array}$ \\
\hline $120 \mathrm{Jam}$ & Keruh keabu-abuan & $\begin{array}{l}\text { Butiran-butiran Biosolar semakin halus dan semakin menipis serta } \\
\text { terbentuk lapisan putih tipis diantara lapisan Biosolar dan media } \\
\text { kultur (sama pada setiap rasio nutrien). }\end{array}$ \\
\hline $144 \mathrm{Jam}$ & $\begin{array}{l}\text { Putih susu } \\
\text { Kecuali Rasio nutrien } 3 \\
\text { (keruh keabu-abuan) }\end{array}$ & $\begin{array}{l}\text { Butiran Biosolar hanya tersisa di tepi permukaan atas media kultur } \\
\text { dan menempel pada dinding Erlenmeyer. Serta lapisan putih yang } \\
\text { terbentuk diatas lapisan media kultur semakin menebal (sama pada } \\
\text { setiap rasio nutrien). }\end{array}$ \\
\hline $168 \mathrm{Jam}$ & Putih susu & $\begin{array}{l}\text { Pada rasio nutrien } 1 \& 2 \text { tidak lagi ditemukan lapisan Biosolar. Pada } \\
\text { rasio nutrien } 3 \& 4 \text {, butiran Biosolar hanya tersisa dalam jumlah yang } \\
\text { sangat sedikit di tepi permukaan atas media kultur dan menempel } \\
\text { pada dinding Erlenmeyer. Serta lapisan putih yang terbentuk diatas } \\
\text { lapisan media kultur semakin menebal }\end{array}$ \\
\hline
\end{tabular}

Ali dan Mukhtasor (2011) menjelaskan Nutrisi dalam proses bioremediasi berperan sebagai sumber ATP, sintesis sel, dan penerima elektron di dalam bioreaksi yang menghasilkan energi. Sedangkan pertumbuhan bakteri yaitu bertambahnya jumlah dan berat sel bakteri yang berlangsung secara teratur. Peranan nutrisi sangat besar dalam proses sintesis sel, pertumbuhan sel, dan dalam kinerja enzim yang diproduksi oleh bakteri dalam mendegradasi pencemaran lingkungan oleh hidrokarbon. Tiga nutrien utama (makronutrien) yang diperlukan bakteri yaitu karbon, nitrogen, dan fosfor.

Sumber energi untuk aktivitas bakteri diperoleh dari Karbon, sedangkan senyawa penting sel yang mempengaruhi aktifitas pertumbuhan mikroba di peroleh dari nitrogen dan fosfor (Nurmalasari, 2018). sehingga jika unsur karbon, nitrogen dan fosfor berada pada perbandingan tidak seimbang akan mengganggu proses metabolisme bakteri. Apabila proses metabolisme bakteri 
terganggu maka aktivitas serta pertumbuhan bakteri tidak akan optimal, hal tersebut akan berdampak terhadap peranan bakteri dalam mendegradasi hidrokarbon.

Berubahnya warna media kultur mengindikasikan bahwa adanya peningkatan jumlah koloni bakteri yang membuktikan bakteri mampu beradaptasi dengan lingkungan yang mengandung hidrokarbon dengan cara memanfaatkan senyawa hidrokarbon yang terkandung dalam Biosolar dalam metabolisme dan pertumbuhannya.

Perubahan warna pada media kultur tersebut juga di ikuti oleh berubahnya kondisi struktur Biosolar pada permukaan media kultur. Kondisi struktur Biosolar yang menutupi lapisan permukaan media kultur berubah menjadi butiran-butiran Biosolar. Butiranbutiran Biosolar yang mulanya berada di permukaan dan strukturnya kasar kemudian berangsur menjadi butiran yang lebih halus serta larut dan menyatu ke dalam media kultur. Hal tersebut menandakan bahwa proses degradasi oleh bakteri sedang berlangsung, yang ditandai oleh Bakteri Bacillus cereus strain IMB-11 yang mulai menghasilkan biosurfaktan sehingga lapisan Biosolar terpecah menjadi butiran-butiran yang lebih kecil.

Biosurfaktan memiliki molekul hidrofilik dan hidrofobik. Molekul tersebut dapat menurunkan tegangan permukaan Biosolar, sehingga terjadi kontak langsung (perlekatan) sel bakteri Bacillus cereus strain IMB-11 dengan permukaan Biosolar yang menyebabkan Biosolar teremuslifikasi ke dalam air kemudian menyebabkan struktur Biosolar terpecah menjadi butiranbutiran kecil. Perlekatan dapat terjadi karena sel bakteri memiliki sifat hidrofobik (tidak larut dalam air). Biosurfaktan mempermudah pelepasan hidrokarbon dan meningkatkan konsentrasi hidrokarbon dalam media degradasi melalui emulsifikasi atau pelarutan (Ristiati, et al., 2016).

Setelah Biosolar terpecah menjadi butiran-butiran dan teremulsifikasi kedalam media kultur, bakteri Bacillus cereus strain IMB-11 akan mendegradasi Biosolar dengan cara menggunakan enzim oksigenase (mono-oksigenase dan dioksigenase). Mono-oksigenase memiliki peran utama dalam proses degradasi hidrokarbon alifatik, sedangkan dioksigenase memiliki peran utama dalam proses degradasi hidrokarbon alisiklik. n-alkana akan dioksidasi menjadi alkohol primer dengan bantuan enzim mono-oksigenase. Selanjutnya alkohol primer dioksidasi menjadi aldehid, lalu menjadi asam lemak dan asetil koenzim A. Senyawa antara asetil Ko-A masuk ke siklus krebs, sehingga rantai karbon berkurang dari $\mathrm{Cn}$ menjadi $\mathrm{Cn}-2$ dan berlanjut hingga hidrokarbon teroksidasi. Hasil akhir biodegradasi yaitu terpotongnya hidrokarbon menjadi rantai yang lebih pendek dan gas. Hal tersebut ditandai oleh semakin berkurangnya Biosolar di dalam media kultur. 
Sedangkan enzim dioksigenase akan mendegradasi PAH (Polisiklik Aromatik Hidrokarbon), selanjutnya membentuk cis-dihidrodiol. Selanjutnya di dehidrogenasi untuk membentuk dihidroksi-PAH yang merupakan substrat bagi enzim dalam membuka cincin karbon. Dengan memberi satu molekul oksigen maka enzim mono-oksigenase dapat mendegradasi PAH dan membentuk arene oksida. Molekul tersebut dimanfaatkan bakteri sebagai sumber nutrisi untuk pertumbuhan dan energy (Hasyimuddin, 2016).

\section{Jumlah koloni Bakteri Bacillus cereus IMB-11}

Jumlah total koloni bakteri Bacillus cereus strain IMB-11 dihitung setiap 24 jam sekali selama 7 hari untuk mengetahui profil pertumbuhan bakteri Bacillus cereus strain IMB-11. Rasio nutrien yang berbeda memberikan profil pertumbuhan yang berbeda pada bakteri Bacillus cereus strain IMB-11. Profil pertumbuhan bakteri Bacillus cereus strain IMB-11 ditampilkan pada gambar 3.

\section{Profil Pertumbuhan Bakteri Bacillus cereus strain IMB-11}

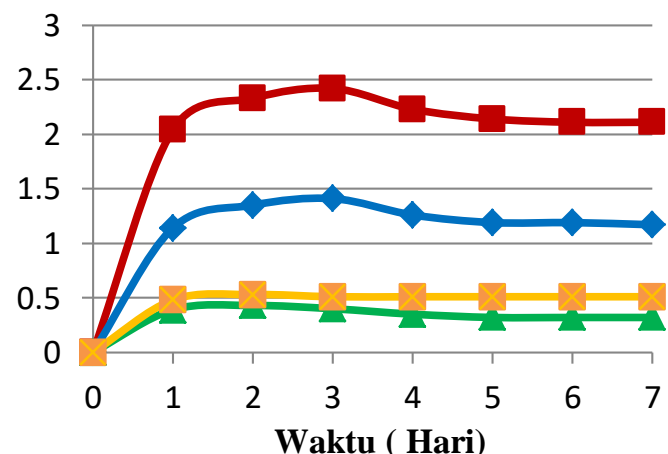

$\rightarrow$ Rasio Nutrien 1 $C: N: P=100: 10: 1$

Rasio Nutrien 2 $\mathrm{C}: \mathrm{N}: \mathrm{P}=100: 10: 0.5$

Rasio Nutrien 3 $\mathrm{C}: \mathrm{N}: \mathrm{P}=100: 5: 1$

Gambar 3. Kurva profil pertumbuhan bakteri Bacillus cereus strain IMB-11 dalam mendegradasi Biosolar

Berdasarkan kurva profil pertumbuhan bakteri pada gambar 4.3, bakteri melewati empat fase pertumbuhan, dimulai fase adaptasi, dilanjutkan fase eksponensial, fase stasioner, dan di akhiri fase kematian. Fase adaptasi pada rasio nutrien 1, 2, 3, dan 4 hampir tidak terlihat, hal tersebut mengindikasikan bahwa bakteri Bacillus cereus strain IMB-11 tidak membutuhkan waktu yang lama untuk beradaptasi dengan lingkungan yang mengandung Biosolar karena bakteri Bacillus cereus strain IMB-11 merupakan bakteri hidrokarbonoklastik yang dapat hidup di lingkungan yang mengandung hidrokarbon dengan cara memanfaatkan karbon sebagai nutrisinya, selain itu, singkatnya fase adaptasi bakteri dikarenakan bakteri tersebut tumbuh pada media yang sama pada saat proses peremajaan. Lama fase adaptasi berbeda-beda tergantung dari jenis bakteri, nutrisi dan media kultur. 
Fase eksponensial pada semua variasi rasio nutrisi terjadi pada hari pertama (24 jam Setelah inkubasi). Pada fase tersebut bakteri mengalami pertumbuhan yang signifikan. Hal tersebut mengindikasikan bahwa bakteri telah beradaptasi dengan baik dan bisa memanfaatkan sumber nutrisi dengan optimal. Pertumbuhan paling signifikan diperlihatkan oleh variasi rasio nutien 1 $(\mathrm{C}: \mathrm{N}: \mathrm{P}=100: 10: 1)$ dengan total pertambahan jumlah koloni $2.04 \times 10^{9}$ CFUlmL. Pada akhir fase eksponensial terjadi penurunan kecepatan pertumbuhan bakteri yang disebabkan nutrien di dalam medium sudah berkurang dan hasil metabolisme yang beracun atau dapat menghambat pertumbuhan bakteri.

Pada hari ke dua dan hari ke tiga bakteri mengalami fase stasioner untuk setiap variasi rasio nutrien. Pada fase stasioner jumlah sel bakteri akan tetap karena jumlah sel yang tumbuh akan sama dengan jumlah sel yang mati, sehingga terjadi keseimbangan laju pertumbuhan bakteri dengan laju kematiannya. Ukuran sel pada fase ini menjadi lebih kecil karena sel akan tetap melakukan pembelahan meski nutriennya sudah habis. Pada fase ini pertumbuhan bakteri juga melambat, hal tersebut disebabkan oleh berkurangnya nutrien dan terjadi penumpukan produk beracun sisa metabolisme bakteri (Ika Nurjannah, 2018).

Fase kematian mulai terjadi pada hari ke empat, dimana jumlah total bakteri mengalami penurunan, tetapi tidak terjadi penurunan secara signifikan. Penurunan jumlah sel dapat diakibatkan nutrien yang mulai berkurang tetapi jumlah total sel bakteri tinggi sehingga menyebabkan kompetisi antar sel bakteri. Selain hal tersebut juga disebabkan oleh sisa ekskresi bakteri yang tertimbun dalam mediua SMSS, yang dapat mengganggu perkembangbiakan dan pertumbuhan bakteri.

Berdasarkan gambar 4.3 terdapat 4 kurva profil pertumbuhan bakteri. Dari ke-empat kurva profil pertumbuhan bakteri tersebut diperoleh bahwa variasi rasio nutrien 1 dengan rasio nutrisi $\mathrm{C}: \mathrm{N}: \mathrm{P}=100: 10: 1$ memberikan pertumbuhan paling optimal terhadap bakteri Bacillus cereus strain IMB-11. Selanjutnya di ikuti oleh rasio nutrien 2 dengan rasio nutrisi C:N:P=100:10:0.5, rasio nutrien 4 dengan rasio nutrisi $\mathrm{C}: \mathrm{N}: \mathrm{P}=100: 5: 0.5$, dan yang terendah adalah rasio nutrien 3 dengan rasio nutrisi $\mathrm{C}: \mathrm{N}: \mathrm{P}=100: 5: 1$.

\section{Analisis Potensi dan Pengembangan Rancangan Poster}

Hasil penelitian optimasi rasio nutrien bakteri Bacillus cereus strain IMB-11 dalam mendegradasi Biosolar dapat digunakan sebagai data primer dalam merancang media pembelajaran poster pada pembelajaran biologi materi Bakteri kelas X SMA. Adapun langkah perancangan poster dilakukan dalam 2 tahap yaitu tahap analisis dan desain. 


\section{Analisis Potensi}

Data yang digunakan adalah data primer berupa optimasi rasio nutrien bakteri Bacillus cereus strain IMB-11 dalam mendegradasi Biosolar. Selanjutnya, dilakukan analisis pada kurikulum 2013 revisi 2018 yaitu KD SMA kelas X. Setelah dilakukan analisis terhadap kompetensi dasar yang terdapat pada kelas $\mathrm{X}$, dan didapatkan kompetensi dasar yang sesuai dengan data primer optimasi rasio nutrien bakteri Bacillus cereus strain IMB-11 dalam mendegradasi Biosolar yaitu KD 3.5 Mengidentifikasi struktur, cara hidup, reproduksi dan peran bakteri dalam kehidupan dan KD 4.5 Menyajikan data tentang ciri-ciri dan peran bakteri dalam kehidupan.

Langkah selanjutnya adalah dilakukan analisis silabus yang digunakan sesuai dengan kurikulum yaitu silabus kurikulum 2013 revisi 2018 KD 3.5 Mengidentifikasi struktur, cara hidup, reproduksi dan peran bakteri dalam kehidupan pada kelas $\mathrm{X}$ berisi materi tentangBakteri.

\section{Perancangan Poster}

Tahap perancangan (design) terdiri dari 2 tahap yaitu: tahap perancangan perangkat pembelajaran dan desain Poster.

\section{Perancangan Perangkat Pembelajaran}

Pada tahap ini dilakukan perancangan perangkat pembelajaran meliputi silabus dan RPP yang telah disesuaikan dengan ketetapan Kemendikbud tahun 2018. Silabus yang dikembangkan yaitu KD 3.5 dan KD 4.5 dengan 4 kali pertemuan, yang direlevansikan dengan hasil penelitian pada materi Eubacteria (Lampiran 1). Adapun rincian materi yang dikembangkan pada KD 3.5 dan 4.5 dapat dilihat pada Tabel 2:.

Tabel 2. Rincian Materi Yang Dikembangkan Pada KD 3.5 Dan 4.5

\begin{tabular}{cl}
\hline Pertemuan & \multicolumn{1}{c}{ Materi } \\
\hline I & Pengertian bakteri, Ciri-ciri bakteri \\
II & Perbedaan bakteri gram negatif dan positif, Cara hidup bakteri. \\
III & Reproduksi bakteri dan Peranan bakteri dalam kehidupan
\end{tabular}

Rencana pelaksaan pembelajaran yang dirancang sesuai dengan data hasil penelitian adalah pembelajaran yang menggunakan pendekatan saintifik yang terdiri atas 5 langkah, yaitu mengamati, menanya, mencoba, menalar dan mengkomunikasikan dengan model Discovery Learning (DL). Penggunaan model Discovery Learning (DL) dengan pertimbangan data hasil penelitian mengenai peranan bakteri merupakan pengetahuan yang memberikan pemahaman berupa konsep pada siswa serta bagaimana siswa dapat membangun pengetahuan berdasarkan pemahaman atau pengalaman awal (Yustina et al., 2018). 
Tahap selanjutnya dilakukan pembuatan poster yang dapat dikembangkan nantinya sebagai media ajar alternatif. Poster yang dirancang peneliti merupakan poster untuk materi Bakteri. Poster ini nantinya akan digunakan pada pembelajaran bakteri pada pertemuan 1, dan dalam pelaksanaan proses pembelajaran akan ditampilkan pada pembelajaran kegiatan inti yaitu pada fase mengamati, sehingga siswa tertarik dalam mengikuti proses pembelajaran. Desain poster tentang peranan bakteri bagi lingkungan dapat dilihat pada Gambar 4.

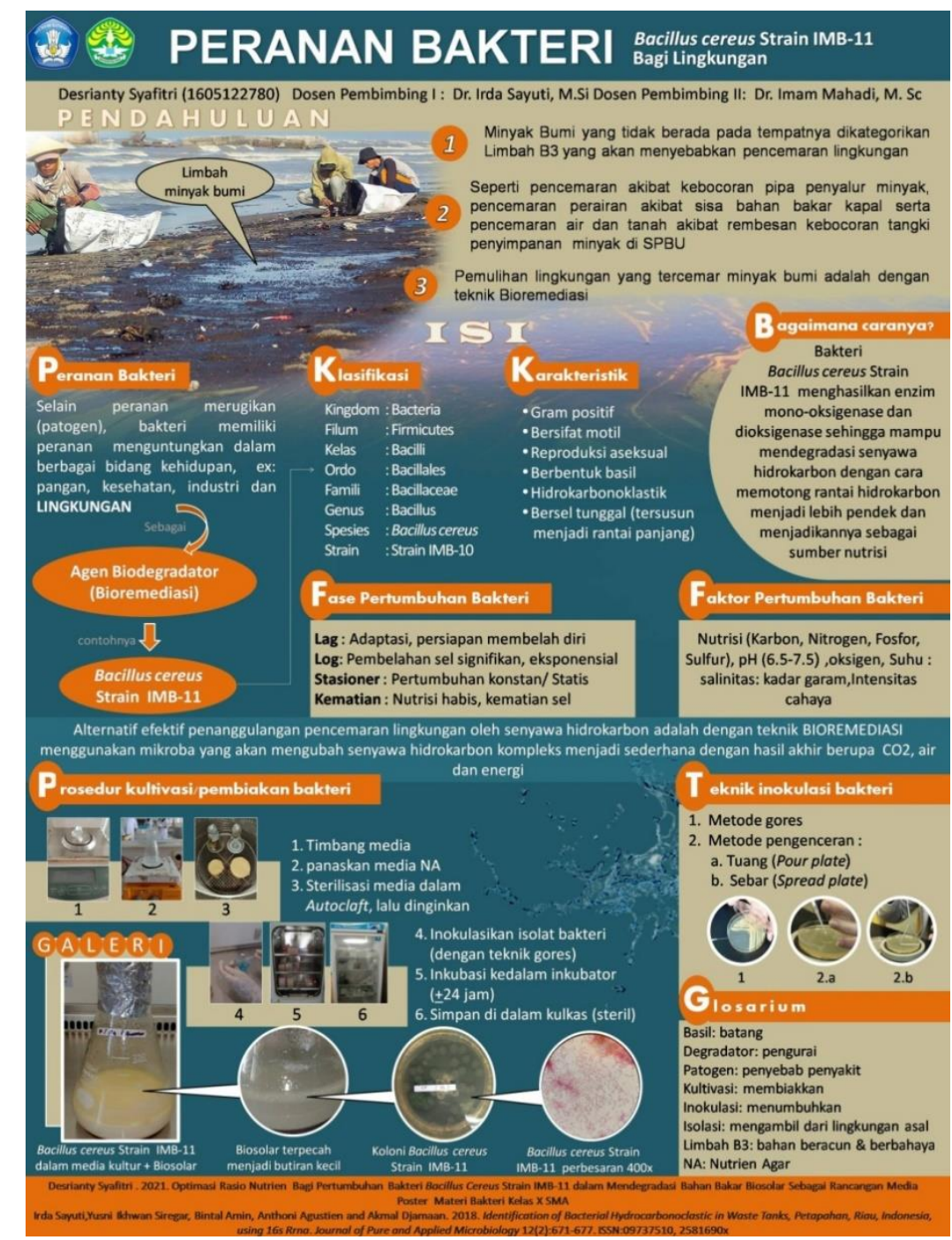

Gambar 4. Rancangan media poster, (Modifikasi Atiko, 2019).

Keterangan format rancangan poster sebagai berikut :

1. Judul

Judul rancangan poster ini adalah "Peranan Bakteri Bacillus cereus strain IMB-11

bagi Lingkungan" yang didasarkan pada indikator pencapaian kompetensi yang dikembangkan dari analisisi KD dan analisis kurikulum serta keterkaitannya dengan data hasil penelitian tentang optimasi rasio nutrien Bakteri Bacillus cereus strain IMB-11 dalam 
mendegradasi Biosolar. Judul ditulis secara singkat dan jelas, hal tersebut bertujuan memudahkan peserta didik atau pembaca untuk memahami pokok bahasan yang terdapat didalam poster hanya dengan membaca judul sepintas lalu. selain itu, penulisan judul juga disesuaikan dengan isi poster yang bertujuan untuk memberikan gambaran secara umum kepada pembaca tentang materi yang dibahas didalam poster.

\section{Nama Pengarang, Nama Pembimbing I dan II}

Nama Pengarang, Nama Pembimbing I dan II merupakan bagian dari identitas poster yang bertujuan untuk memberikan informasi tentang penulis dan yang turut membantu dalam proses penelitian serta proses pengembangan poster. Penulisan identitas poster juga bertujuan untuk menghindari plagiarisme.

\section{Pendahuluan}

Pada bagian pendahuluan berisi penjelasan tentang materi bakteri secara umum, meliputi pengertian bakteri dan peranan bakteri. Pada bagian ini juga memuat sebuah gambar berupa permasalahan atau fenomena lingkungan dalam kehidupan yang sesuai dengan isi materi yang akan dibahas di dalam poster, hal tersebut bertujuan mengarahkan siswa kedalam suatu topik pembelajaran. Gambar tersebut juga dilengkapi dengan pernyataan-pernyataan singkat dan jelas yang bertujuan untuk menarik perhatian siswa agar membaca kelanjutan isi poster.

\section{Isi}

Bagian isi poster disesuaikan dengan KD 3.5 yaitu Mengidentifikasi struktur, cara hidup, reproduksi dan peran bakteri dalam kehidupan, dan KD 4.5 Menyajikan data tentang ciri-ciri dan peran bakteri dalam kehidupan. Serta disesuaikan dengan indikator pencapaian kompetensi yang telah disesuaikan dengan data hasil penelitian. Isi poster memuat tentang nutrisi bakteri dan keterkaitannya dengan proses bakteri dalam mendegradasi Biosolar. Pada bagian isi juga ditampilkan gambar dari bakteri Bacillus cereus strain IMB-11 yang dilengkapi dengan gambar animasi struktur bakteri agar memudahkan siswa dalam mengidentifikasi struktur bakteri.

Pada bagian isi juga dikaitkan dengan data hasil penelitian, seperti jenis bakteri, faktor yang mempengaruhi pertumbuhan bakteri, serta peranan bakteri. yang bertujuan agar siswa mendapatkan informasi bahwa bakteri mempunyai peranan bagi lingkungan, khususnya peranan menguntungkan seperti sebagai biodegradator dalam proses bioremediasi dan 
peranan tersebut bisa di optimalkan dengan cara mengoptimalkan faktor-faktor tumbuh dari bakteri tersebut.

5. Sumber

Bagian ini memuat sumber data dari isi poster serta referensi-referensi yang digunakan dalam merancang media poster. Referensi ini bertujuan mempermudah siswa dalam mencari sumber belajar.

\section{KESIMPULAN}

Rasio nutrien $\mathrm{C}: \mathrm{N}: \mathrm{P}=10: 10: 1$ memberikan pertumbuhan lebih optimal terhadap bakteri Bacillus cereus Strain IMB-11 dibandingkan dengan rasio nutrien lainnya dengan jumlah total koloni terbanyak yaitu $2.42 \times 10^{9} \mathrm{CFU} / \mathrm{mL}$. Hal tersebut dapat memacu proses pengendalian pencemaran lingkungan oleh biosolar menggunakan agen biodegradator bakteri Bacillus cereus Strain IMB-11 berjalan lebih cepat dan efektif. Dan hasil penelitian dapat dijadikan sebagai rancangan media poster materi Bakteri kelas X SMA 3.5 Mengidentifikasi struktur, cara hidup, reproduksi dan peran bakteri dalam kehidupan dan KD 4.5 Menyajikan data tentang ciri-ciri dan peran bakteri dalam kehidupan.

\section{DAFTAR PUSTAKA}

Ali, M., dan Mukhtasor. (2011). Proses Biostimulasi dengan Optimasi Nutrien Untuk Bioremediasi

Tanah Tercemar Tumpahan Minyak Mentah Dikawasan Pantai. Jurnal Ilmiah Teknik Lingkungan. 3(1). ISSN 2085-501- X

Andareas, P. (2019). Biodegradasi Minyak Solar Menggunakan Isolat Bakteri Indigenous Mangrove Tritih Kulon, Cilacap. Jurnal Kridatama Sains dan Teknologi. Universitas Ma`arif Nahdhatul Ulama. Vol 1(1): 18-27. e-ISSN:2685-6921

Atiko. (2019). Booklet, Brosur, dan Poster sebagai Karya Inovatif di Kelas. Caremedia Communication. Jawa Timur.

Hasyimuddin, D., N., Samawi, F. (2016). Isolasi Bakteri Pendegradasi Minyak Solar Dari Perairan Teluk Pare-Pare. Jurnal Biogenesis. Vol 4(1): 41-46. ISSN 2302-1616

Kristinanda, A., D. (2018). "Isolasi Bakteri Pendegradasi Senyawa Hidrokarbon Di Tanah Tercemar Di Balai Yasa Pt. Kai Yogyakarta”. Skripsi. Program Studi Teknik Lingkungan, Universitas Islam Indonesia Musfiqon. (2012). Pengembangan Media dan Sumber Pembelajaran. Prestasi Pusdakarya. Jakarta 
Ningsih, I., R., K. (2018). "Pengembangan Media Pembelajaran Poster Berbasis Pictorial Riddle Untuk Meningkatkan Minat Dan Hasil Belajar Fisika Siswa Kelas X Sma Negei 1 Jogonalan”. Skripsi. Fakultas Matematika Dan Ilmu Pengetahuan Alam. Universitas Negeri Yogyakarta

Nurjannah, I. (2018). “Uji Potensi Bakteri Pendegradasi Minyak Solar Di Perairan Pelabuhan Tanjung Perak Surabaya". Skripsi. Program Studi Ilmu Kelautan Fakultas Sains Dan Teknologi Universitas Islam Negeri Sunan Ampel Surabaya.

Nurmalasari, R. (2018). "Bioremediasi Tanah Terkontaminasi Solar Menggunakan Variasi Kultur Campuran Bakteri Dan Rasio Nutrien". Tesis. Departemen Teknik Lingkungan Fakultas Teknik Sipil, Lingkungan Dan Kebumian Institut Teknologi Sepuluh Nopember Surabaya.

Permendikbud Nomor 37 Tahun 2018 tentang Kompetensi Dasar dan Kompetensi Inti SD SMP dan SMA.

Ristiati, Sanusi, Putra. (2016). Uji Kemampuan Degradasi Minyak Solar Oleh Konsorsium Bakteri Hasil Preservasi Dengan Kombinasi Metode Liofilisasi Dan Metode Gliserol. Prosiding Seminar Nasional MIPA. Fakultas Matematika dan IPA Undiksha. ISBN 978-602-6428-00$4:(258-267)$.

Sayuti, I., Ikhwan, Y., S., Amin, B., Agustien, A., dan Djamaan, A. (2018). Identification of Bacterial Hydrocarbonoclastic in Waste Tanks, Petapahan, Riau, Indonesia, using 16s Rrna. Journal of Pure and Applied Microbiology. 12(2) : 671-677. ISSN: 09737510, 2581690x

Ulum, A., Z.. (2017). Pengaruh Pemanfaatan Media Poster Terhadap Perilaku Siswa dalam Menjaga Kebersihan Lingkungan di Kelas II MI Nashrul fajar Meteseh Tembalang. Skripsi Dipublikasikan. Universitas Islam Negeri Walisongo. Semarang.

Wulan, P., Gozan, M., Berly Arby dan Bustomy, A. (2019). Penentuan Rasio Optimum C:N:P Sebagai Nutrisi Pada Proses Biodegradasi Benzena-Toluena Dan Scale Up Kolom Bioregenerator. Artikel ilmiah. Fakultas Teknik, Universitas Indonesia, Depok.e-ISSN:25021680

Yustina, Darmawati, Apriandi, R. (2018). Strategi Pembelajaran Biologi. UR Press. Pekanbaru. 